\title{
Ormancılık üretim işlerinde iş kazaları üzerine bir araştırma
}

\author{
Zehra Çetinkaya a,* (id
}

\begin{abstract}
Özet: İş kazaları dünyada ve Türkiye'de her yıl çok ciddi bir sorun olarak insanların hayatını etkilemektedir. Bu nedenle, iş sağlı̆̆ı ve güvenliği çalışmalarının daha etkin bir şekilde uygulanması gerektiği düşünülmektedir. Ormancılık uygulamaları genel olarak, yüksek risk grubu içeren sektörler arasında yer almaktadır. Bu gerekçeden hareketle çalışmamızda, ormancılıkta üretim işlerinde işçilerin iş kazası geçirme oranları, bazı alışkanlıkları ve kaza nedenleri araştırılmıştır. Adana, Ankara, Bolu, Çorum, Erzincan, Kocaeli, Sinop ve Tokat Orman İşletme Müdürlükleri bünyesinde üretim işlerinde çalışan toplam 111 ișçi ile yapılan anketlerden elde edilen veriler kullanılmıștır. Elde edilen verilere göre; orman iş̧ilerinden \%15'inin en az bir defa iş kazası geçirdiği, kaza nedenlerinin ise başlıca çalışma yeri zorluğu, aşırı yorgunluk-uykusuzluk, bigisizlikeğitimsizlik, olumsuz hava koşulları, koruyucu ekipman eksikliği, işi hafife alma-dikkatsizlik, tecrübesizlik, uygun olmayan alet-makine kullanımı, yetersiz ve düzensiz beslenme olduğu belirlenmiştir. Ayrıca, orman sahalarında meydana gelen iş kazalarının en aza indirilmesi ve orman işçilerine daha iyi şartlar sunabilmek adına önerilerde bulunulmuştur.

Anahtar Kelimeler: Orman, iş güvenliği, iş kazaları, kaza nedenleri
\end{abstract}

\section{Investigation of occupational accidents at the forestry harvesting activities}

Abstract: Occupational accidents are affecting human life each year causing serious problems in Turkey and around the world. For this reason, it is seen that there is a need for more occupational health and safety studies. Forestry is one of the sectors with a high risk group in general. In this study, In this study, occupational accident ratio and some habits of forest harvesting workers, and the reasons of the accidents were investigated. The data obtained from a total of 111 forest workers responded to a self-administered questionnaire working at the harvesting practises at Directorates of Forest Enterprises Adana, Ankara, Bolu, Çorum, Erzincan, Kocaeli, Sinop and Tokat were used. According to findings; $15 \%$ of forestry workers had at least an occupational accident and the causes of accidents were determined as difficulty of workplace, excessive fatigue-sleeplessness, ignorance-lack of education, adverse weather conditions, deficiency of personal protection equipment and carelessness. Suggestions were made in order to minimize the occupational accidents in forest areas and to offer better conditions to the forest workers.

Keywords: Forest, work safety, occupational accidents, reasons of the accidents

\section{Giriş}

Orman işleri, ağırlık ve tehlike açısından en zor iş bölümleri arasındadır. Uluslararası Çalışma Örgütü’nün çalışmalarında da genelde 3D (dirty, difficult and dangerous) sektörleri arasında gösterilmektedir. Bir başka ifadeyle ormancılık uygulamaları; zorlu koşullarda, hijyenik olmayan ve tehlikeli iş kavramının İngilizce ilk harfleri olan 3D ile tanımlanmaktadır (Poschen 1993). Orman işleri, ağırlıklı olarak çalışma bölgeleri açık alanlar olduğu için uygun olmayan iklim şartları, sorunlu arazi durumları, yerleşkelerden oldukça uzak olması, iyi bir beslenmenin olmaması, yavaş çalışma, su kaynaklarının sağlıklı olmaması, gelişen ve ilerleyen teknolojiye karşı yaşanan uyum sorunu, güvenliğin yeterli olmaması, yeterli ve doğru eğitimi almadan işe başlama, çoğu zaman ayakta çalışma vb. gibi etkenler sebebiyle çoğu zaman tehlikeye açık bir konumdadır (Menemencioğlu 2012).

Bütün bunlara ilaveten; yüksek enerji tüketimi, statik çalışma yoğunluğu, ağır yükler kaldırılması ve taşınması, eğilme, diz çökme ve kalkma hareketlerinin sıkça tekrarlanması, aşırı sıcaklık, yüksek rutubet, rüzgar, kar ve yağmur gibi iklim faktörlerine açık olması, gürültü, vibrasyon, gaz, toz, kimyasal maddeler gibi olumsuz teknolojik etkiler, merkezi sinir sistemi, iskelet sistemi, kalp-dolaşım sistemi gibi insanın başlıca sistemlerinde oluşturduğu sağlık bozuklukları ve vücudun potansiyel olarak bütün organlarına yönelik kaza riskleri ormancılık faaliyetlerini ağır işler arasına sokmaktadır. Ayrıca, ormancılık faaliyetlerinde kaza tehlikesinin ötesinde bir de uzun süre sonra kendisini gösteren kronik hastalık risklerinin oranı da oldukça yüksektir (Menemencioğlu 2006).

Ormancılıkta üretim işleri denince; ağacın kesilerek devrilmesi, dallarının kesilmesi, gerektiğinde kabuklarının soyulması, bölümlere ayırma ve sınıflandırma işleri, elde edilen ürünlerin bölmeden çıkarılması, yükleme, taşıma, istifleme ve son depoya ulaştırılması anlaşılmaktadır. Belirtilen tüm bu iş safhaları sırasında birçok iş kazaları meydana gelebilmektedir (Menemencioğlu 2012).

Ülkemizde Sosyal Güvenlik Kurumu (SGK) istatistiklerine göre, orman iş sahalarında 2015 yılında 434, 2016 yılında 345, 2017 y1lında 447, 2018 yılında 486 ve 2019 yılı sonuçlarında ise 508 iş kazası kaydı olduğu belirtilmiştir (Şekil 1).

\footnotetext{
a Merkezi Araştırma Laboratuvarı, Çukurova Üniversitesi, Adana, Türkiye

* Corresponding: zcetinkaya@cu.edu.tr

Received: 15.09.2021, Accepted: 17.10.2021
}

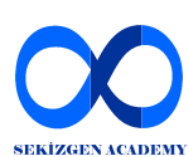

Citation: Çetinkaya, Z. (2021). Ormancılık üretim işlerinde iş kazaları üzerine bir araştırma. Theoretical and Applied Forestry 2: 44-50. doi: $10.53463 /$ tafor.2021vol1iss2pp44-50 


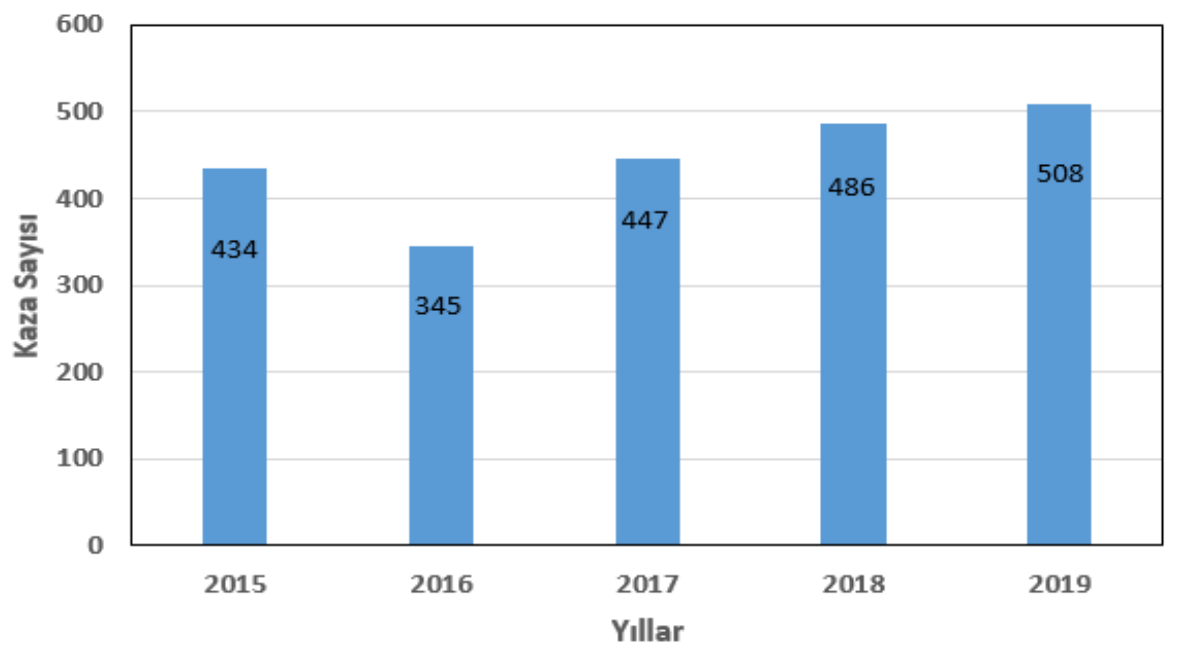

Şekil 1. 2015-2019 Yılları arası ormancılık faaliyetlerinde meydana gelen iş kazası sayıları (SGK).

Bu çalışmada da, orman işçilerinin 8 farklı bölgeden elde edilen iş kazası geçirme oranları, bazı alışkanlıkları ve kaza nedenleri incelenmiştir. Çalışma sahalarında meydana gelen iş kazalarının önüne geçilmesi ve orman işçilerine daha iyi şartlar sunulabilmesi için bazı önerilerde bulunulmuştur.

\section{Materyal ve metot}

\subsection{Materyal}

$\mathrm{Bu}$ çalışma, Orman Genel Müdürlüğüne bağlı üretim işletmelerinde çalışan işçilere anket yöntemi ile yapılmıştır. $\mathrm{Bu}$ çalışmanın anket gruplarını, ülkemizin 8 farklı bölgesinde orman işlerinde çalışan 35'i kadın ve 76'sı erkek olmak üzere toplam 111 orman işçisi oluşturmaktadır. Birinci grup anket çalışması; Adana Orman Bölge Müdürlüğü/Pos Orman İşletme Müdürlüğü bünyesinde çalışan toplam 14 orman işçisine uygulanmıştır. İkinci grup anket çalışması; Ankara Orman Bölge Müdürlüğü/Ankara Orman İşletme Müdürlügü bünyesinde çalışan 19 işçiye, üçüncü grup anket çalışması ise; Bolu Orman Bölge Müdürlüğü/Kıbrıscık Orman İşletme Müdürlüğü alanlarında çalışan toplam 49 işçiye uygulanmıştır. Dördüncü anket grubunu; Amasya Orman Bölge Müdürlüğü/Çorum Orman İşletme Müdürlüğü alanlarında çalışan 6 işçi ve beşinci anket grubunu da Erzurum Orman Bölge Müdürlüğü/Erzincan Orman İşletme Müdürlüğü alanlarında çalışan toplam 7 orman işçisi oluşturmaktadır. Altıncı anket grubunu; Sakarya Orman Bölge Müdürlüğü/Adapazarı Orman İşletme Müdürlügü alanlarında çalışan toplam 4 işçi oluşturmaktadır. Yedinci grup anket çalışmasını; Kastamonu Orman Bölge Müdürlüğ̈̈/Sinop Orman İşletme Müdürlüğü alanlarında çalışan toplam 8, sekizinci ve son grubu ise Amasya Orman Bölge Müdürülüğü/Tokat Orman İşletme Müdürlüğü alanlarında çalışan 4 adet orman işçisi oluşturmuştur.

\subsection{Metot}

Çalışma kapsamında orman İşçilerine toplamda 21 soru sorulmuş olup, ad ve soyadı yazmalarına gerek olmadığı belirtilmiştir. Ankete katılan işçilerin kaza sayısı verilerini, iş kazalarına karşı farkındalıklarını, sosyal durumlarını-bazı alışkanlıklarını ve işçilerin işten beklentilerini tespit etmek için durum tespit anketi uygulanmıştır.

\section{Bulgular ve tartışma}

$\mathrm{Bu}$ çalışmada, orman üretim faaliyetleri sırasında meydana gelen iş kazalarıyla ilgili olarak Adana, Ankara, Bolu, Çorum, Erzincan, Kocaeli, Sinop ve Tokat bölgelerinde çalışan toplam 111 orman işçisinden elde edilen veriler değerlendirilmiştir. $\mathrm{Bu}$ işçiler üretim işlerinde çalışmaktadırlar.

Anket sorularının hazırlanmasında, Acar ve Şentürk'ün (1997, 1999) yapmış oldukları benzer çalışmalardan faydalanılmıştır. Araştırmaya katılanların cinsiyet dağılımları Şekil 2'de verilmiştir.

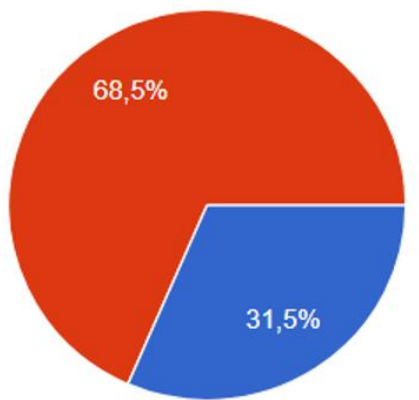

Şekil 2. Araştırmaya katılanların cinsiyet dağılımı

Şekil 2 incelendiğinde; işçilerin \% 68.5'inin erkeklerden oluştuğu görülmektedir. Bu durum büyük oranda, orman üretim işlerinin fiziki güç gerektiren ağır iş grubunda yer almasından kaynaklanmaktadır. 
Yaş gruplarına göre; 15-30 yaş arasında olanların \% 51.4 ile en yüksek oranda, 31-45 yaş arasında olanların \% 35.1 oranında ve 46 yaşından büyük olanların ise \% 13.5 oranında olduğu tespit edilmiştir (Şekil 3).
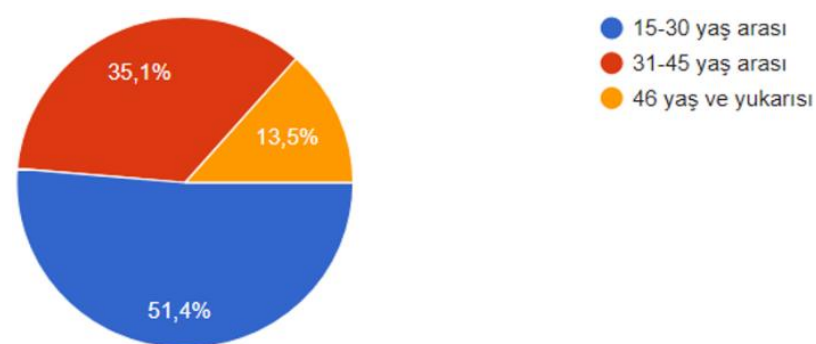

Şekil 3. Araştırmaya katılanların yaş dağılımı

İşçilerin; \% 30.6's1 üniversite, \% 34.2'si lise, \% 15.3'ü ortaokul \% 13.5'i ise ilkokul mezunudur. Okuryazar olmayanların oranı ise \% 6.3'tür (Şekil 4).

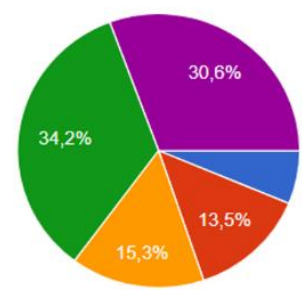

- Herhangi bir ŏğretim kurumundan mezun değilim

illkokul mezunu

- Ortaokul mezunu

- Lise mezunu

- Universite mezunu

Şekil 4. Araştırmaya katılanların eğitim dağılımı

Çalışma sürelerine bakıldığında ise, 1-5 yıldır orman işinde çalışanların \% 45 oranla en yüksek düzeyde olduğu bulunmuştur (Şekil 5).
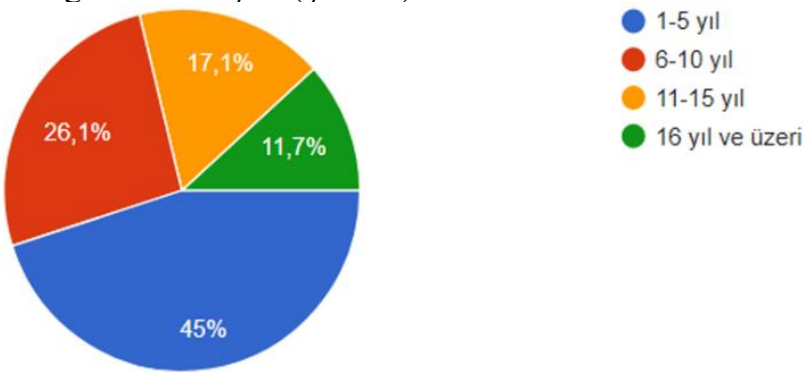

Şekil 5. Araştırmaya katılanların çalışma sürelerinin dağılımı

Çalışanların \% 53.2'si evli, \% 37.8'si bekar, \% 6.3'ü boşanmış, \% 2.7'sinin ise eşi vefat etmiştir (Şekil 6).
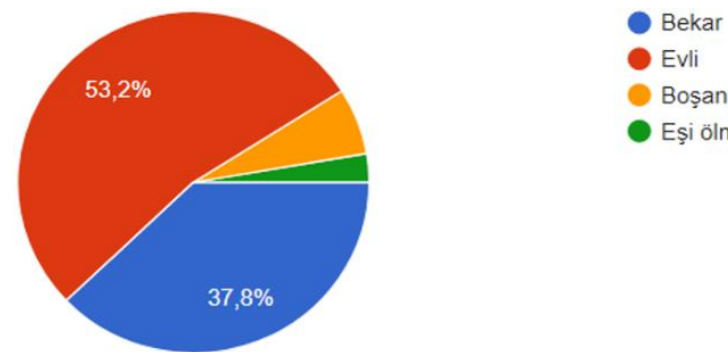

Evli

Boșanmıș

Eşi ölmüș (dul)

Şekil 6. Araștırmaya katılanların medeni durumlarının dağılımı
Aile nüfusu bakımından, ankete katılan işçilerin \% 37.8'i 1-3 kişilik aileden oluşmakta, \% 5.4'ünde ailedeki kişi sayıs1 6'dan fazla, \%35.1'i ise 4-6 kişiden oluşmaktadır. \% 21.6'sı ise yalnız yaşamaktadır (Şekil 7).
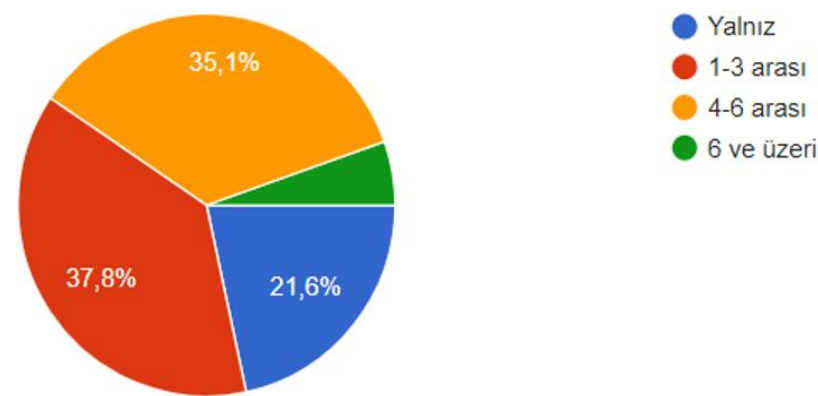

Şekil 7. Araştırmaya katılanların aile nüfusu (kişi) dağılımı

Çalışanların \% 21.6'sı başta hayvancılık ve tarım olmak üzere ek iş yapmakta, \% 17.1'i ise diğer ek işlerle uğraşmakta ve \% 61.3'ü ise ek iş yapmamaktadır (Şekil 8).
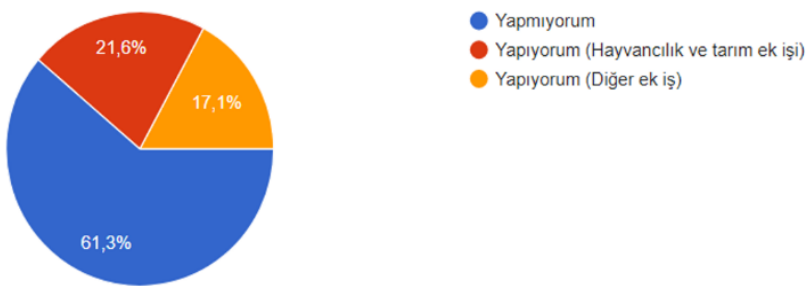

Şekil 8. Araştırmaya katılanların ek iş dağılımı

Şekil 9 incelendiğinde ise kazancını yeterli bulanlar \% 50.5 , bulmayanlar ise $\% 49.5$ oranındadır.

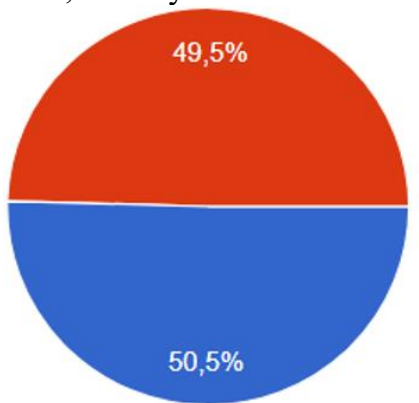

Evet Hayır

Şekil 9. Araştırmaya katılanların kazançlarını yeterli bulan-bulmayan dağılımı

Çalışanların \% 64.9 gibi büyük bir kısmı işini severek yaptığını, \% 23.4'ü ise zamanla alıştığını ifade etmiştir. Alışamadığını ifade edenler ise \% 11.7 oranındadır (Şekil $10)$. 


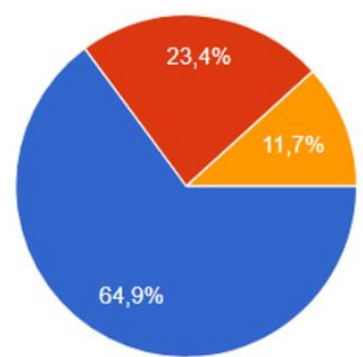

Şekil 10. Araştırmaya katılanların çalıştığ işe olan ilgilerinin dağılımı

Şekil 11 incelendiğinde ise, ilkyardım malzemesini yeterli bulanların oranı \% 63.1 olup, \% 36.9'u yetersiz olduğunu belirtmiştir. Orman işçiliğinde, çalışma yerinin sağlık kuruluşlarına uzaklığı göz önünde bulundurulmalı ve bu eksikliklerin giderilmesi için gerekli düzenlemeler yapılmalıdır.

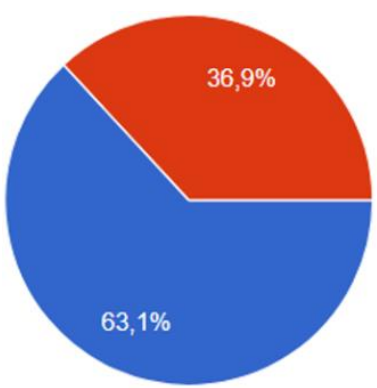

Evet yeterl Hayır değil

Şekil 11. Araştırmaya katılanların ilkyardım malzemesini yeterli-yetersiz bulan dağılımı.

İşçilerin \% 50.5'i sigara kullanmamaktadır. Sigara kullananların \% 32.1'i günde 1 paketten az, \% 17.1' $\mathrm{i}$ ise günde 1 paketten fazla sigara kullanmaktadır (Şekil 12).
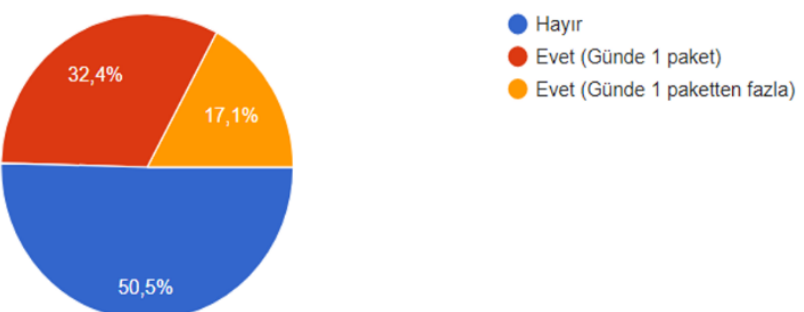

Şekil 12. Araştırmaya katılanların sigara kullanımı dağılımı

Şekil 13 incelendiğinde ise, işçiler arasında düzenli spor yapanlar \% 33.3 olarak bulunmuştur.

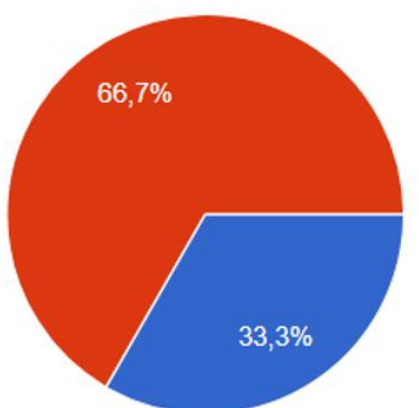

Evet

Hayır

Şekil 13. Araştırmaya katılanların düzenli spor yapma dağılımı

Düzenli diş firçalayanlar ise \% 65.5 olarak bulunmuştur (Şekil 14). Şekil 15 incelendiğinde ise düzenli kahvaltı yapanların oranı \% 74.8 olarak tespit edilmiştir.

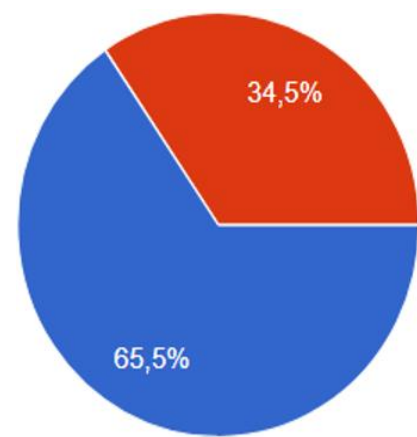

Evet

Hayır

Şekil 14. Araştırmaya katılanların düzenli diş firçalama dağılımı

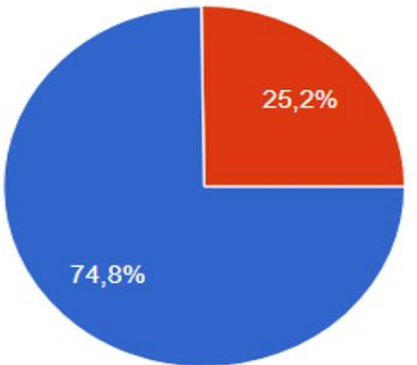

Evet

Şekil 15. Araştırmaya katılanların düzenli kahvaltı yapma dağılımı

Şekil 16 incelendiğinde ise; hiç kaza geçirmediğini belirtenlerin oranı \% 69.4'tür. Geriye kalanının \% 15.3'ü 1 defa, \% 10.8'i 2-3 defa, \% 4.5'i de 4 defadan fazla iş kazası geçirdiğini belirtmiştir.

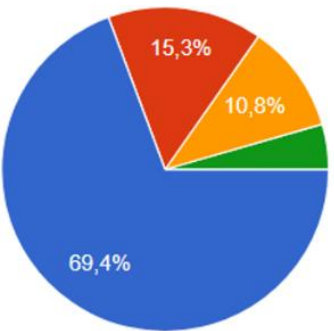

Hiç geçirmedim - Geçirdim (bir kez) Geçirdim (2-3 defa)

- Geçirdim (4 ve üzeri)

Şekil 16. Araştırmaya katılanların iş kazası geçirme dağılımı 
İş kazası geçirenlerde kaza şekli, \% 47.5'inde yaralanma (kesilme-zedelenme), \% 52.5'inde kirılma, burkulma ve çarpma şeklinde kazalar olduğu sonucu ortaya çıkmıştır. Yaralanma olayı daha çok \% 16 oranında el-kol, \% 13 oranla ayak-bacakta görülmüştür. Ayrıca, \% 5 oranla gövde, \% 2'şer oranla baş ve kalça yaralanmaları şeklinde gerçekleşmiştir (Şekil 17).

Anket çalışmalarına baktığımızda bu yaşanan kazaların nedenlerinin; \% 42.4'ünün çalışma yeri zorluğu, \% 36'şar oranla kişisel koruyucu ekipman eksikliği ile olumsuz hava koşullarından, \% 24.2'ü aşırı yorgunluk ve uykusuzluktan, \% 18.2'sinin bilgisizlik-eğitimsizlikten, $\%$ 15.2'sinin işi hafife alma-dikkatsizlik, \% 9'ar oranla tecrübesizlik ile uygun olmayan alet ve makine kullanımından, \% 2'sinin de yetersiz ve düzensiz beslenme kaynaklı olduğu görülmektedir (Şekil 18).

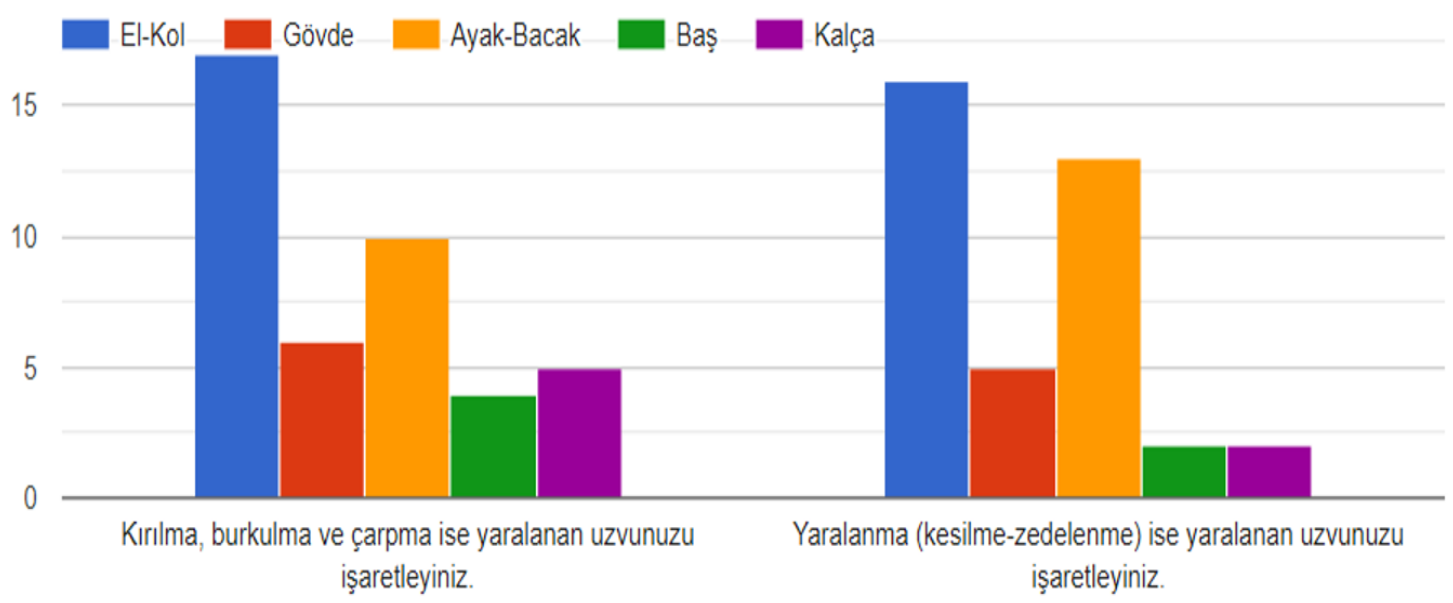

Şekil 17. Araştırmaya katılanların kaza şekli ve vücuttaki bölge dağılımı

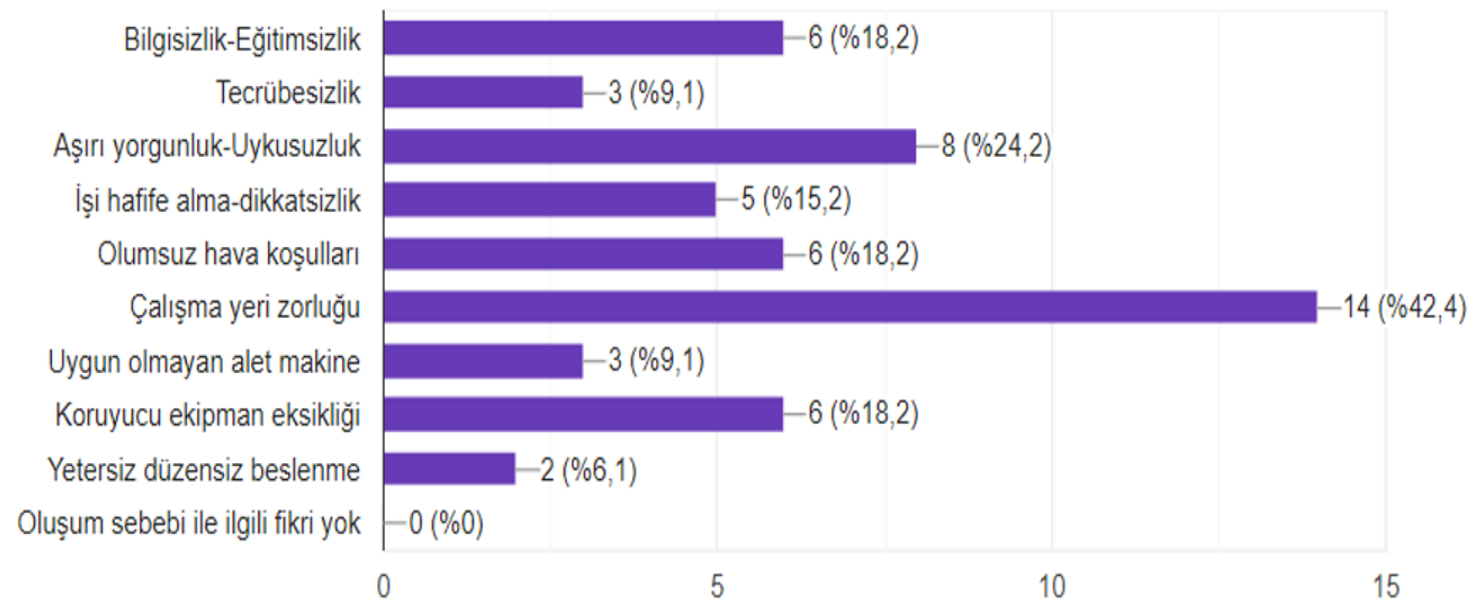

Şekil 18. Yaşanan iş kazalarının nedenleri

Yapılan çalışmada; sağlık yönünden kendini mükemmel hissedenlerin oran1 \% 27, iyi hissedenlerin oran1 \% 65.8 ve kötü hissedenlerin oranı da \% 7.2 olarak bulunmuştur (Şekil 19).

Böcek 1sırıkları (arı), alerjen bitki ağaç polenleri gibi insanda travmatik sonuçlar doğuran (anaflaksi gibi) Alerji testinden geçtiniz mi? sorusuna işçilerin \% 37.8'i evet ve \% 44.1'i hayır cevabını vermişlerdir. \% 18 ise eskiden (çocukluk, gençlik çağlarında) alerji testine girdiklerini belirtmişlerdir (Şekil 20).

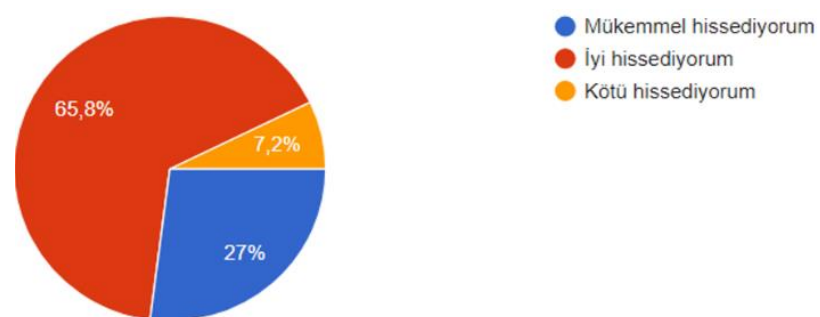

Şekil 19. Araştırmaya katılanların sağlık yönünden nasıl hissettiklerinin dağılımı 

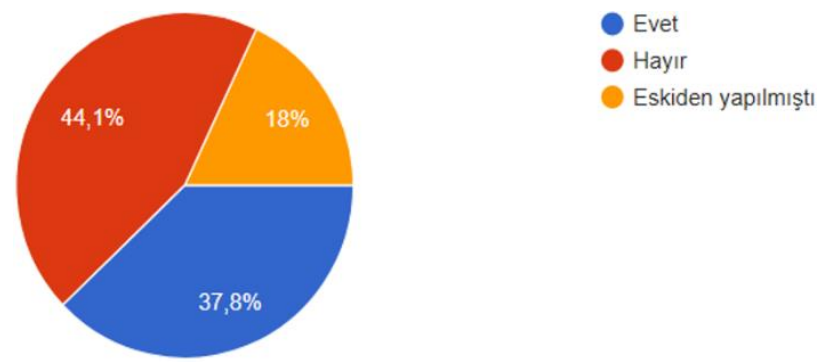

Şekil 20. Araştırmaya katılanların arı sokması, böcek isırığı ve polene karşı alerji testinin dağılımı

Şekil 21 incelendiğinde; Kırım Kongo Kanamalı Ateşi hastalığı hakkında bilgi sahibi olanların oranı \% 64.9'dur. Geriye kalanlar ise, bilgi sahibi olmadıklarını belirtmişlerdir.

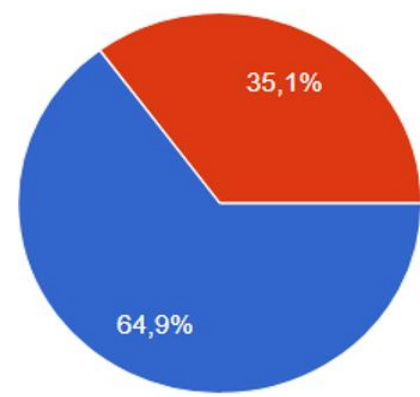

Evet Hayır

Şekil 21. Araştırmaya katılanların kırım kongo kanamalı ateşi hasatalığı hakkındaki bilgi dağılımı

Yapılan çalışmada, iş sağlı̆ğ ve güvenliği eğitimi alanların oranı \% 80.2'dir. Geriye kalanların \% 9.9'u eğitim almadığını, \% 9.9'u da konu hakkında fikri olmadığını belirtmiştir. (Şekil 22).
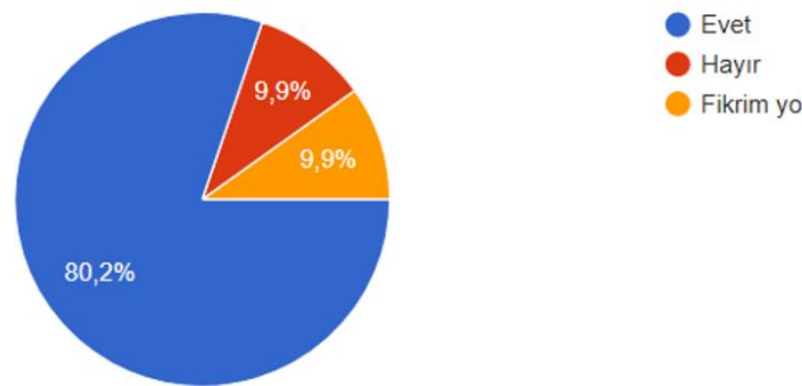

Şekil 22. Araştırmaya katılanların iş sağlığı ve güvenliği eğitimi alma dağılımı

\section{Sonuçlar}

Adana, Ankara, Bolu, Çorum, Erzincan, Kocaeli, Sinop ve Tokat bölgelerinde orman işlerinde çalışan işçilerle yapılan anket çalışmalarından elde edilen verilerin değerlendirilmesiyle aşağıdaki sonuçlar ortaya çıkmıştır. Buna göre; Orman üretim işleri fiziki güç gerektirdiğinden dolayı genelde daha çok erkek işçilerin çalıştığı sonucuna varılmıştır.

Yapılan çalışmada iş kazası hiç geçirmeyenlerin oranı \% 69.4 olarak belirlenmiştir. Kaza şekli olarak daha çok kırılma, burkulma ve çıkma gibi ortopedik rahatsızlıklar ile yaralanma (kesilme-zedelenme) olaylarına rastlanılmıştır. Ortopedik olaylar daha çok kol, ayak, bilek, gövde ve kalçada görülürken, yaralanma olayına en çok el-kol, ayak-bacak ve gövdede rastlanmıştır.

Kaza nedenleri incelendiğinde; \% 42.4 oranla çalışma yeri zorluğu en büyük kaza nedeni olarak görülmektedir. Zorlu arazi şartları, taşlı, dikenli çalılıkların yoğun şekilde oluşu, hava koşulları da dahil iş kazaları en çok dikkatsizlik sonucu oluşmaktır.. Kaza nedenlerinden bir diğeri ise kişisel koruyucu ekipman eksikliğidir. Kişisel koruyucu ekipman kullanımı mutlaka sağlanmalı, işçilere konunun önemi anlatılmalı ve gerekli denetlemeler yapılmalıdır. Ayrıca aşırı yorgunluk ve uykusuzluk da önemli kaza nedenlerinden biridir. Orman üretim işlerinde çalışan işçiler birim fiyat üzerinden ücretlerini almaktadırlar. $\mathrm{Bu}$ nedenle işçiler daha fazla ücret alabilmek adına kapasitelerini zorlayarak çalışmakta ve aşırı yorgun-uykusuz halleri ortaya çıkabilmektedir. $\mathrm{Bu}$ durum iş̧̧ilerin iş kazası geçirme riskini arttırmaktadır.

Ormancilık faaliyetlerinde iş kazalarına neden olan kötü çalışma koşulları, yetersiz beslenme, uygun olmayan alet-makine kullanımı veya kişisel koruyucu ekipman eksikliği, yetersiz eğitim gibi olumsuzlukların azaltılmasına veya ortadan kaldırılmasına yönelik gerekli düzenlemeler yapılmalıdır.

Arı sokması, böcek ısırığı ve polene karşı alerji riski bulunan işçilerin alerji testinden geçirilmesi gereklidir. Anafilaksi arı sokmasından hemen sonra meydana gelir, işçinin nefes borusu şişer ve nefes alması zorlaşır (Lee ve Vadas 2011). Çalışma alanının orman sahası olduğu düşünülürse kaza geçiren iş̧̧inin yaşamı en yakın hastaneye ulaşım süresinin kısalığına bağlı olacaktır (Triggiani vd. 2008). Ormancılık çalışmaları için, işçilerin önceden sağlık muayenesinden geçmeleri ve bu muayenede alerji testine de tabi tutulmaları gerekmektedir. İş̧ilerin \% 35.1'i Kırım-kongo hastalı̆ğ hakkında bilgi sahibi olmadığını belirtmiştir. KırımKongo kanamalı ateşi hastalığ 1 için gerekli koruyucu iş ekipmanı ve eğitimi işçilere verilmelidir.

Ormancılık işlerinin yapıldığı alanlarda çalışan orman işçilerinin sahadaki güvenliği için risk faktörleri belirlenmeli ve bu riskler ya tamamen ortadan kaldırılmalı ya da minimum seviyeye düşürücü önlemler alınmalıdır. Ayrıca yaralanmaların ve sakatlanmaların önüne eçilmesi için işçilere mevcut eğitimler sürekli verilerek ormancılık faaliyetlerinde çalışan işçilere iş güvenliği bir kültür haline dönüştürülmelidir. 


\section{Kaynaklar}

Acar H.H, Şentürk N (1997). Yusufeli ve İskenderun yöresindeki orman ișçilerinde işçi sağllğ 1 üzerine bir araştırma,. İ.Ü. Orman Fakültesi Dergisi, 47(2): 95-109.

Acar H.H, Şentürk N (1999). Artvin yöresindeki orman işçilerinde işçi sağlığı üzerine bir araştırma. İ.Ü. Orman Fakültesi Dergisi, 49 (1): 25-39.

Lee J.K, Vadas P (2011). Jul. Anaphylaxis: mechanisms and management. Clinical and experimental allergy: journal of the British Society for Allergy and Clinical Immunology 41(7): 92338.
Menemencioğlu K (2006). Ormancılıkta üretim işlerinde çalışma koşulları ve iş kazaları üzerine araştırma. Süleyman Demirel Üniversitesi Orman Fakültesi Dergisi, A(2): 1-12.

Menemencioğlu K (2012). Tarım ve orman işçiliğinde çalıșma yeri koşulları ve karşılaşılan sorunlar. Türk Bilimsel Derlemeler Dergisi, 5(2): 72-76.

Poschen P (1993). Forestry, A Safe and Healthy Profession. Unasylva, 44(1): 172.

Triggiani M, Patella V, Staiano R.I, Granata F, Marone G (2008). Allergy and the cardiovascular system. Clinical and experimental immunology, 153(1): 7-11. 